\title{
EVALUASI PROGRAM SERTIFIKASI KOMPUTER PADA UNIVERSITAS TEKNOLOGI INDONESIA MENGGUNAKAN MODEL CSE-UCLA
}

\section{Dewa Gede Hendra Divayana1, Gusti Ayu Dessy Sugiharni²}

\author{
1Jurusan Pendidikan Teknik Informatika, Universitas Pendidikan Ganesha, Indonesia \\ 2Jurusan Sistem Komputer, STMIK STIKOM Bali, Indonesia
}

E-mail: hendra.divayana@undiksha.ac.id

\begin{abstract}
Abstrak
Penelitian ini bertujuan untuk mengetahui efektivitas pelaksanaan program sertifikasi komputer pada Universitas Teknologi Indonesia. Penelitian ini tergolong penelitian evaluatif dengan menggunakan model CSE-UCLA yang terdiri dari komponen system assesment, program planning, program implementation, program improvement dan program certification. Subjek penelitian ini terdiri dari: kepala laboratorium, tim pengelola sertifikasi, dan mahasiswa. Metode pengumpulan data dilakukan dengan kuesioner, observasi, wawancara, dan dokumentasi. Teknik analisis data dalam penelitian ini adalah deskriptif kuantitatif untuk menganalisis persentase tingkat efektivitas tiap-tiap komponen dalam model CSE-UCLA dan deskriptif kualitatif untuk menganalisis kendala-kendala yang menyebabkan hasil evaluasi tidak sesuai dengan standar keberhasilannya. Hasil evaluasi program sertifikasi komputer pada Universitas Teknologi Indonesia menunjukkan bahwa rata-rata tingkat efektivitas pelaksanaan program pada komponen system assesment sebesar $84,73 \%$, program planning sebesar $83,87 \%$, program implementation sebesar $85,24 \%$, program improvement sebesar $84,17 \%$, dan program certification sebesar $84,75 \%$. Dengan melihat rata-rata hasil evaluasi pelaksanaan program sertifikasi komputer pada Universitas Teknologi Indonesia secara keseluruhan yaitu sebesar $84,55 \%$ maka tingkat efektivitas pelaksanaan program tergolong kategori baik.
\end{abstract}

Kata Kunci: CSE-UCLA, Sertifikasi Komputer, Evaluasi Program

\begin{abstract}
This study aims to determine the effectiveness of the implementation of computer certification program at Universitas Teknologi Indonesia. This research is classified evaluative research used by CSE-UCLA model that consist of: system assessment component, program planning, program implementation, program improvement and certification programs. Subjects of this study consist of: head of the laboratory, the team manager of the certification, and students. Methods of data collection is done by questionnaires, observations, interviews, and documentation. Data analysis techniques in this research is descriptive quantitative to analyze the percentage of the effectiveness of each component in the model CSE-UCLA and descriptive qualitative to analyze the constraints that led to the evaluation results are not in accordance with the standards of success. The results of the evaluation of computer certification program at the University of Technology Indonesia showed that the average level of effective implementation of the program on the assessment system components by $84.73 \%$, $83.87 \%$ of program planning, program implementation amounted to $85.24 \%, 84.17 \%$ for program improvement, and amounted to $84.75 \%$ certification program. By looking at the average results of the evaluation of computer certification program at the University of Technology Indonesia as a whole amounted to $84.55 \%$, the level of effectiveness of the implementation of the program belong to either category.
\end{abstract}

Keywords: CSE-UCLA, Computer Certification, Program Evaluation 


\section{PENDAHULUAN}

Dengan diberlakukannya masyarakat ekonomi ASEAN (MEA), maka akan berdampak pada persaingan yang semakin ketat di dunia kerja. Salah satu upaya yang dapat dilakukan untuk menghadapi persaingan yang ketat tersebut adalah dengan mempersiakan tenaga kerja yang memiliki kompetensi tinggi. Untuk mendapatkan tenaga kerja yang kompeten, maka dapat dilakukan melalui jalur pendidikan formal, pendidikan non formal, serta sertifikasi kompetensi. Jalur pendidikan formal yaitu melalui pendidikan D3, S1, S2, dan S3. Jalur pendidikan non formal yaitu melalui pelatihan/kursus. Jalur sertifikasi kompetensi yaitu melalui uji kompetensi/keahlian. Universitas Teknologi Indonesia sebagai salah satu perguruan tinggi yang menyelenggarakan pendidikan formal berusaha untuk meningkatkan kompetensi lulusannya, dengan cara mengadakan uji kompetensi. Salah satu bentuk uji kompetensi yang diselenggarakan yaitu sertifikasi komputer bagi mahasiswa jurusan teknik informatika, yang dilaksanakan sebelum mahasiswa mengambil skripsi.

Alasan utama diselenggarakan sertifikasi komputer di Universitas Teknologi Indonesia adalah untuk mempersiapkan lulusan yang memiliki kompetensi tinggi dan siap bersaing dalam mencari kerja. Hal tersebut dikarenakan dalam persaingan kerja di era MEA, para pencari pekerja tidak bisa hanya mengandalkan ijazah, namun yang paling dibutuhkan adalah kompetensi yang dapat ditunjukkan dengan adanya sertifikat kompetensi. Sertifikasi komputer sebagai salah satu bentuk program pendidikan yang diselenggarakan oleh Universitas Teknologi Indonesia ternyata masih ditemukan kendala-kendala dalam pelaksanaannya. Oleh karena itu, perlu dilaksanakan evaluasi terhadap program tersebut. Salah satu bentuk model evaluasi yang digunakan yaitu CSE-UCLA. Alasan penggunaan model ini dikarenakan model CSE-UCLA sangat cocok untuk mengevaluasi program layanan pendidikan, salah satunya yaitu program sertifikasi komputer. Aspek-aspek yang terdapat pada program sertifikasi komputer Universitas Teknologi Indonesia dievaluasi menggunakan lima komponen evaluasi CSE-UCLA yaitu: System Assesment, Program Planning, Program Implementation, dan Program Certification. Dari hasil evaluasi tersebut nantinya akan dapat digunakan untuk mengambil keputusan terhadap program sertifikasi komputer tersebut yaitu apakah program masih layak untuk diteruskan ataukah tidak.

Remmer (1967), mendefiisikan evaluasi sebagai "a process for describing an evaluand and judging its merit and worth". (suatu proses untuk menggambarkan evaluan (orang yang dievaluasi) dan menimbang makna dan nilainya). Petri (1986) juga berpendapat "evaluation is a process through which a value judgement or decision is made from a variety of observations and from the background and training of the evaluator". Evaluasi adalah suatu proses dimana pertimbangan atau keputusan suatu nilai dibuat dari berbagai pengamatan, latar belakang serta pelatihan dari evaluator). Dari dua rumusan tentang evaluasi ini, dapat kita peroleh gambaran bahwa evaluasi adalah suatu proses yang sistematis dan berkelanjutan untuk menentukan kualitas (nilai dan arti) daripada sesuatu, berdasarkan pertimbangan dan kriteria tertentu untuk membuat suatu keputusan.

Evaluasi adalah sebuah proses mulai dari menggambarkan, mendapatkan dan memaparkan berbagai informasi yang berguna untuk menetapkan sebuah pilihan putusan (Rosyanda, 2004). Evaluasi adalah suatu proses mengumpulkan, menganalisis dan menginterpretasikan informasi yang didapat melalui pengukuran untuk memberikan beberapa makna berdasarkan pertimbangan nilai (Oriondo dan Antonio, 1998). Evaluasi adalah proses memahami, memberi arti, mendapatkan dan mengkomunikasikan suatu informasi bagi keperluan pengambil keputusan (Sukardi, 2008). Evaluasi merupakan proses menilai sesuatu berdasarkan kriteria atau tujuan yang ditetapkan, yang selanjutnya diikuti dengan pengambilan keputusan atas objek yang dievaluasi (Djaali dan Mulyono, 2004). Evaluasi dapat diartikan sebagai penentuan kesesuaian antara hasil yang dicapai dan 
tujuan yang ingin dicapai (Mardapi, 2012). Berdasarkan beberapa pendapat di atas dapat diambil suatu sintesis secara umum bahwa evaluasi merupakan suatu kegiatan untuk mengumpulkan, memahami, dan melaporkan hasil analisis tentang suatu program/objek tertentu sehingga hasilnya dapat digunakan untuk pertimbangan dalam mengambil suatu keputusan apakah program tersebut dilanjutkan ataukah dihentikan.

Evaluasi yang sering dipahami selama ini dalam dunia pendidikan adalah terbatas pada penilaian saja. Penilaian ini dilakukan secara formatif dan sumatif. Ketika sudah dilakukan penilaian, dianggap sudah melakukan evaluasi. Pemahaman demikian tidaklah terlalu tepat. Pelaksanaan penilaian cenderung hanya melihat capaian tujuan pembelajaran saja. Pada hal, dalam proses pendidikan tersebut bukan hanya nilai yang dilihat, tetapi ada banyak faktor yang membuat berhasil atau tidaknya sebuah program. Penilaian hanya bagian kecil dari evaluasi. Evaluasi juga harus dipahami sebagai bagian dari supervisi. Evaluasi tidak hanya berurusan pada nilai yang diukur berdasarkan penyelesaian soal-soal, tetapi evaluasi programpendidikan akan mengkaji banyak faktor. Dengan demikian evaluasi program perlu diperkenalkan kepada seluruh pendidik, karena evaluasi sangat penting dalam pengembangan mutu pendidikan.

Menurut Gall, Gall and Borg (2007) "educational evaluation is the process of making judgments about the merit, value, or worth of educational programs". Dapat diartikan bahwa evaluasi pendidikan adalah proses membuat penilaian tentang prestasi, nilai, atau nilai program pendidikan. Stufflebeam dan Shinkfield (2007) mengutip The Joint Committee's (1994) untuk mendefinisikan evaluasi "evaluation is the systematic assessment of the worth or merit of

an

object". Dalam buku The Program Evaluation Standards yang ditulis oleh Donald B. Yarbrough (2010). Selain itu mengutip Joint Committee on Standards for Educational Evaluation (JCSEE, 1994) defined evaluation as the "systematic investigation of the worth or merit of an object". Dapat diartikan bahwa evaluasi sebagai "penyelidikan sistematis nilai atau manfaat dari sebuah objek". Lebih lanjut diuraikan Donald B. Yarbrough dkk (2010) bahwa: In the third edition, we expand the descriptive definition of program evaluation to include; the systematic investigation of the quality of programs, projects, subprograms, subprojects, and/or any of their components or elements, together or singly; for purposes of decision making, judgments, conclusions, findings, new knowledge, organizational development, and capacity building in response to the needs of identified stakeholders; leading to improvement and/or accountability in the users programs and systems and ultimately contributing to organizational or social value.

Wirawan (2011) mengatakan bahwa: "evaluasi sebagai riset untuk mengumpulkan, menganalisis, dan menyajikan informasi yang bermanfaat mengenai objek evaluasi, menilainya dan membandingkannya dengan indikator evaluasi dan hasilnya dipergunakan untuk mengambil keputusan mengenai objek evaluasi". Owen (2006:20) menjelaskan temuan-temuan evaluasi yang mencakup evidence, conclusions, judgments, and recommendations, yang dapat diartikan sebagai arti dari evaluasi tersebut: Findings encompass the following: Evidence. The data and other information which has been collected during the evaluation. Conclusions. the synthesis of data and information. These are the meanings those involved in the evaluation make though the synthesis of data. This involves evaluators in data display, data reduction and verification processes. Judgments. Placing value on conclusions. Criteria are applied to the conclusions stating that the program is 'good' or 'bad', or that the results are 'positive', 'in the direction desired', or 'below expectations'. Recommendations. These are suggested courses of action, advice to policy-makers, program managers or providers about what to do in the light of the evidence and conclusions.

Evaluasi program dapat disimpulkan sebagai suatu proses pencarian informasi, penemuan informasi dan penetapan informasi yang dipaparkan secara sistematis tentang perencanaan, nilai, tujuan, manfaat, 
efektifitas dan kesesuaian sesuatu dengan kriteria dan tujuan yang telah ditetapkan.

Evaluasi merupakan suatu proses berkelanjutan tentang pengumpulan dan penafsiran informasi untuk menilai keputusan-keputisan yang dibuat dalam merancang suatu sistem pembelajaran. Pengertian tersebut memiliki tiga imlikasi rumusan. Berikut ini implikasi tersebut: Evaluasi adalah suatu proses yang terus menerus, sebelum, sewaktu dan sesudah proses belajar mengajar; Proses evaluasi senantiasa diarahkan ke tujuan tertentu, yakni untuk mendapatkan jawaban-jawaban tentang bagaimana memperbaiki pengajaran dan Evaluasi menuntut penggunaan alat-alat ukur yang akurat dan bermakna untuk mengumpulkan informasi yang dibutuhkan guna membuat keputusan. Evaluasi berkenaan dengan proses yang berhubungan dengan pengumpulan informasi yang memungkinkan kita menentukan: Tingkat kemajuan pengajaran; Ketercapaian tujuan pembelajaran dan Bagaimana berbuat baik pada waktu-waktu mendatang. Evaluasi meliputi pengukuran dan penilaian. Pengukuran berakaitan dengan ukuran kuantitatif, sedangkan penilaian terkait dengan kualitas (Suharsimi Arikunto). Perencanaan evaluasi pembelajaran berarti persiapan atau pemikiran guru tentang pengukuran dan penilaian proses dan hasil kegiatan belajar mengajar.

Evaluasi pembelajaran memilki berbagai tujuan diantaranya adalah untuk : Menentukan angka kemajuan atau hasil belajar pada siswa. Berfungsi sebagai: Laporan kepada orang tua / wali siswa; Penentuan kenaikan kelas dan Penentuan kelulusan siswa. Penempatan siswa ke dalam situasi belajar mengajar yang tepat dan serasi dengan tingkat kemampuan, minat dan berbagai karakteristik yang dimiliki. Mengenal latar belakang siswa (psikologis, fisik dan lingkungan) yang berguna baik bagi penempatan maupun penentuan sebab-sebab kesulitan belajar para siswa, yakni berfungsi sebagai masukan bagi tugas Bimbingan dan Penyuluhan (BP). Sebagai umpan balik bagi guru, yang pada gilirannya dapat digunakan untuk memperbaiki proses belajar mengajar dan program remdial bagi siswa.
Evaluasi mempunyai fungsi: Kurikuler (alat pengukur ketercapaian tujuan mata pelajaran), instruksional (alat ukur ketercapaian tujuan proses belajar mengajar), diagnostik (mengetahui kelemahan siswa, penyembuhan atau penyelesaian berbagai kesulitan belajar siswa), placement (penempatan siswa sesuai dengan bakat dan minatnya, serta kemampuannya) dan administratif BP (pendataan berbagai permasalahan yang dihadapi siswa dan alternatif bimbingan dan penyuluhanya).

Model evaluasi CSE-UCLA yang dikembangkan oleh Alkin memiliki lima macam tahapan evaluasi, yaitu: system assesment, program planning, program implementation, program improvement, dan program certification (Tayibnapis, 2000). Hal senada diungkapkan oleh Suryanto, Gafur, dan Sudarsono bahwa evaluasi CSEUCLA yang dikembangkan oleh Alkin mengevaluasi program dalam lima tahap evaluasi yaitu: system assesment, program planning, program implementation, program improvement, dan program certification (Suryanto, Gafur, dan Sudarsono, 2013).

Berdasarkan beberapa pendapat di atas dapat diambil suatu sintesis secara umum bahwa model CSE-UCLA merupakan model evaluasi yang memiliki lima dimensi evaluasi, antara lain system assesment yang memberikan informasi tentang keadaan sistem, program planning yang membantu pemilihan program tertentu untuk memenuhi kebutuhan program, program implementation yang menyiapkan informasi untuk memperkenalkan program, program improvement yang memberikan informasi tentang fungsi/kinerja program, program certification yang memberi informasi tentang manfaat atau guna program.

\section{METODE}

Penelitian ini tergolong penelitian evaluatif dengan menggunakan model CSE-UCLA yang terdiri dari komponen system assesment, program planning, program implementation, program improvement dan program certification. Subjek penelitian ini terdiri dari: kepala laboratorium, tim pengelola sertifikasi, dan mahasiswa. Metode pengumpulan data dilakukan dengan kuesioner, observasi, 
wawancara, dan dokumentasi. Teknik analisis data dalam penelitian ini adalah deskriptif kuantitatif untuk menganalisis persentase tingkat efektivitas tiap-tiap komponen dalam model CSE-UCLA dan deskriptif kualitatif untuk menganalisis kendala-kendala yang menyebabkan hasil evaluasi tidak sesuai dengan standar keberhasilannya. Analisis data tentang pelaksanaan evaluasi program sertifikasi komputer pada Universitas Teknologi Indonesia ditinjau dari komponen system assesment, program planning, program implementation, program improvement, dan program certification menggunakan teknik analisis deskriptif kuantitatif.
HASIL PENELITIAN DAN PEMBAHASAN

Standar Keberhasilan Evaluasi Program Sertifikasi Komputer pada Universitas Teknologi Indonesia dengan menggunakan Model CSE-UCLA Dalam penggunaan model evaluasi CSE-UCLA untuk mengevaluasi program sertifikasi komputer pada Universitas Teknologi Indonesia, maka terlebih dahulu disusun standar keberhasilan evaluasi yang ditunjukkan pada Tabel 1. Adapun kategori skala standar efektivitas/ keberhasilan adalah Sangat Baik (90\%-100\%), Baik (80\%-89\%), Cukup (70\%-79\%), Kurang (60\%-69\%), dan Sangat Kurang (0\%-59\%).

Tabel 1. Standar Keberhasilan Evaluasi Program Sertifikasi Komputer Pada Universitas Teknologi Indonesia Dengan Menggunakan Model CSE-UCLA

\begin{tabular}{|c|c|c|c|}
\hline No & $\begin{array}{l}\text { Komponen } \\
\text { Evaluasi }\end{array}$ & Aspek Yang Dievaluasi & $\begin{array}{c}\text { Standar Efektivitas/ } \\
\text { Keberhasilan (\%) }\end{array}$ \\
\hline \multirow{4}{*}{1.} & & Tujuan & $>=82$ \\
\hline & System Assesment & Dasar Hukum & $>=85$ \\
\hline & & Pedoman & $>=85$ \\
\hline & & Penyiapan Perangkat Keras & $>=85$ \\
\hline \multirow[t]{2}{*}{2.} & Program Planning & Penyiapan Perangkat Lunak & $>=85$ \\
\hline & & Penyiapan SDM & $>=82$ \\
\hline \multirow{3}{*}{3.} & & Pemasangan Perangkat Keras & $>=85$ \\
\hline & $\begin{array}{l}\text { Imogram } \\
\text { Implementation }\end{array}$ & Instalasi Perangkat Lunak & $>=85$ \\
\hline & & Pelatihan SDM & $>=85$ \\
\hline 4 & Program & Pengelolaan Sistem & $>=85$ \\
\hline 4. & Improvement & Pemberdayaan Teknis SDM & $>=85$ \\
\hline 5. & Program Certification & Sertifikat Kompetensi & $>=85$ \\
\hline
\end{tabular}

Hasil Evaluasi Program Sertifikasi Komputer pada Universitas Teknologi Indonesia dengan menggunakan Model CSE-UCLA. Adapun hasil evaluasi program sertifikasi komputer pada Universitas Teknologi Indonesia menggunakan model evaluasi CSE-UCLA, ditunjukkan pada Tabel 2.

Tabel 2. Hasil Evaluasi Program Sertifikasi Komputer Pada Universitas Teknologi Indonesia Menggunakan Model Evaluasi CSE-UCLA

No Komponen Evaluasi Aspek Yang Dievaluasi Hasil Evaluasi (\%)

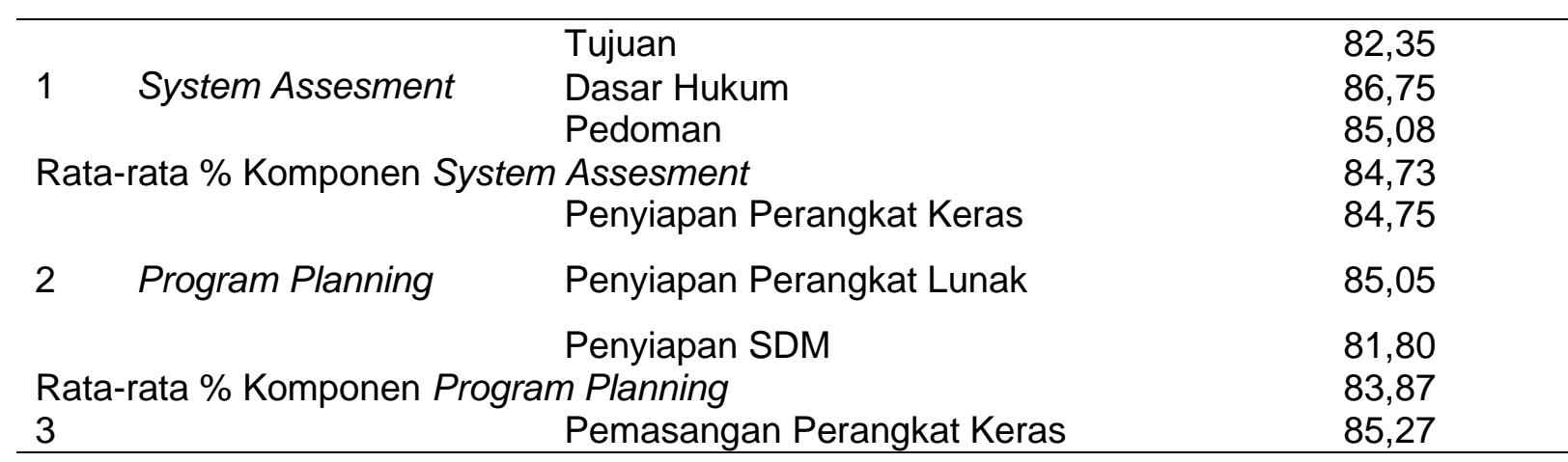


No Komponen Evaluasi

Aspek Yang Dievaluasi

Hasil Evaluasi (\%)
85,42

Perangkat Lunak

Pelatihan SDM

85,04

85,24

84,78

83,56

84,17

84,75

5 Program Certification Sertifikat Kompetensi

Rata-rata \% Komponen Program Certification

84,55

Dari tabel 2 tersebut dapat divisualisasikan ke bentuk pie diagram sebagai berikut.

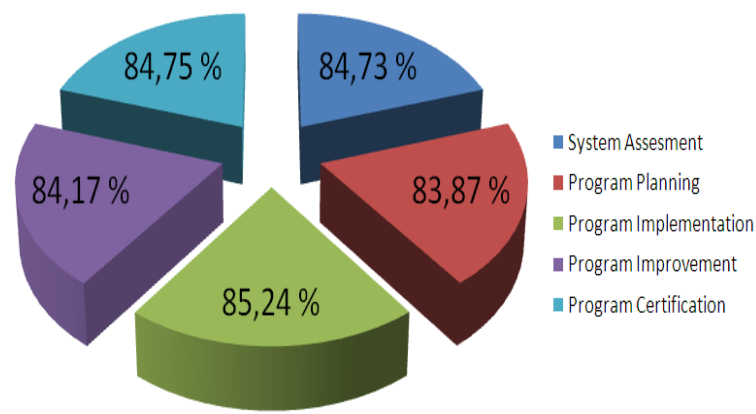

Gambar 1. Diagram Pie Hasil Evaluasi Program Sertifikasi Komputer Pada Universitas Teknologi Indonesia Menggunakan Model Evaluasi CSE-UCLA

Berdasarkan hasil penelitian yang telah dijelaskan, maka ada beberapa hal yang dibahas, antara lain sebagai berikut. Berdasarkan hasil penelitian yang ditunjukkan pada tabel 2 dan secara visualisasi melalui gambar 1 dapat dijelaskan bahwa tingkat efektivitas komponen system assesment sebesar $84,73 \%$. Hasil tersebut diperoleh berdasarkan rerata dari persentase hasil evaluasi terhadap beberapa aspek evaluasi komponen system assesment antara lain: tujuan penyelenggaraan, dasar hukum penyelenggaraan, dan pedoman terselenggaranya program sertifikasi komputer pada Universitas Teknologi Indonesia. Secara umum, hasil tersebut menunjukkan bahwa tingkat efektivitas pelaksanaan program sertifikasi komputer pada Universitas Teknologi Indonesia jika ditinjau dari komponen system assesment termasuk kategori baik.
Tingkat efektivitas komponen program planning sebesar $83,87 \%$. Hasil tersebut diperoleh berdasarkan rerata dari persentase hasil evaluasi terhadap beberapa aspek evaluasi komponen program planning antara lain: penyiapan perangkat keras, penyiapan perangkat lunak, penyiapan sumber daya manusia yang dibutuhkan untuk mendukung penyelenggaraan program. Secara umum, hasil tersebut menunjukkan bahwa tingkat efektivitas pelaksanaan program sertifikasi komputer pada Universitas Teknologi Indonesia jika ditinjau dari komponen program planning termasuk kategori baik.

Tingkat efektivitas komponen program implementation sebesar $85,24 \%$. Hasil tersebut diperoleh berdasarkan rerata dari persentase hasil evaluasi terhadap beberapa aspek evaluasi komponen program implementation antara lain: pemasangan perangkat keras, instalasi perangkat lunak, pelatihan sumber daya manusia yang dipersiapkan sebagai pelaksana penyelenggaraan program. Secara umum, hasil tersebut menunjukkan bahwa tingkat efektivitas pelaksanaan program sertifikasi komputer pada Universitas Teknologi Indonesia jika ditinjau dari komponen program implementation termasuk kategori baik.

Tingkat efektivitas komponen program improvement sebesar $84,17 \%$. Hasil tersebut diperoleh berdasarkan rerata dari persentase hasil evaluasi terhadap beberapa aspek evaluasi komponen program improvement antara lain: pengelolaan sistem, pemberdayaan kemampuan teknis sumber daya manusia yang terlibat dalam penyelenggaraan 
program. Secara umum, hasil tersebut menunjukkan bahwa tingkat efektivitas pelaksanaan program sertifikasi komputer pada Universitas Teknologi Indonesia jika ditinjau dari komponen program improvement termasuk kategori baik.

Tingkat efektivitas komponen program certification sebesar $84,75 \%$. Hasil tersebut diperoleh berdasarkan rerata dari persentase hasil evaluasi terhadap aspek evaluasi komponen program certification yaitu sertifikasi kompetensi yang menunjukkan keberhasilan dalam penyelenggaraan program. Secara umum, hasil tersebut menunjukkan bahwa tingkat efektivitas pelaksanaan program sertifikasi komputer pada Universitas Teknologi Indonesia jika ditinjau dari komponen program certification termasuk kategori baik.

Berdasarkan rata-rata persentase keseluruhan komponen CSE-UCLA yaitu sebesar $84,55 \%$, maka hasil tersebut menunjukkan bahwa tingkat efektivitas pelaksanaan program sertifikasi komputer pada Universitas Teknologi Indonesia jika ditinjau dari seluruh komponen evaluasi model CSE-UCLA termasuk kategori baik. Berdasarkan standar efektivitas/ keberhasilan pada tabel 1 dan hasil penelitian yang ditunjukkan pada tabel 2, maka dapat dijelaskan bahwa tidak ditemukan kendala dalam pelaksanaan program sertifikasi komputer jika ditinjau dari komponen system assesment. Hal tersebut dikarenakan persentase hasil evaluasi terhadap tiap aspek-aspek pada komponen system assesment sudah melewati batas minimum standar efektivitas/keberhasilan yang telah ditetapkan. Pelaksanaan program sertifikasi komputer jika ditinjau dari komponen program planning ditemukan beberapa kendala, khusus dalam hal penyiapan perangkat keras dan penyiapan SDM. Hal tersebut dikarenakan persentase hasil evaluasi terhadap aspek penyiapan perangkat keras masih dibawah batas minimum standar efektivitas/keberhasilan $85 \%$ yang telah ditetapkan, sedangkan persentase hasil evaluasi terhadap aspek penyiapan sumber daya manusia juga masih dibawah batas minimum standar efektivitas/keberhasilan $82 \%$ yang telah ditetapkan.
Tidak ditemukan kendala dalam pelaksanaan program sertifikasi komputer jika ditinjau dari komponen program implementation. Hal tersebut dikarenakan persentase hasil evaluasi terhadap tiap aspek-aspek pada komponen program implementation sudah melewati batas minimum standar efektivitas/keberhasilan yang telah ditetapkan. Pelaksanaan program sertifikasi komputer jika ditinjau dari komponen program improvement ditemukan beberapa kendala, khusus dalam hal pengelolaan sistem dan kemampuan teknis sumber daya manusia yang terlibat dalam penyelenggaraan program. Hal tersebut dikarenakan persentase hasil evaluasi terhadap aspek pengelolaan sistem masih dibawah batas minimum standar efektivitas/ keberhasilan $85 \%$ yang telah ditetapkan, sedangkan persentase hasil evaluasi terhadap aspek kemampuan teknis sumber daya manusia yang terlibat dalam penyelenggaraan program juga masih dibawah batas minimum standar efektivitas/ keberhasilan $85 \%$ yang telah ditetapkan. Pelaksanaan program sertifikasi komputer jika ditinjau dari komponen program certification ditemukan kendala dalam sertifikasi kompetensi. Hal tersebut dikarenakan persentase hasil evaluasi terhadap aspek sertifikasi kompetensi masih dibawah batas minimum standar efektivitas/keberhasilan $85 \%$ yang telah ditetapkan.

\section{SIMPULAN DAN SARAN}

Berdasarkan hasil penelitian dan pembahasan sebelumnya, maka dapat ditarik beberapa kesimpulan antara lain: Tingkat efektivitas pelaksanaan program sertifikasi komputer pada Universitas Teknologi Indonesia ditinjau dari komponen system assesment sebesar 84,73\%, sehingga termasuk kategori baik; Tingkat efektivitas pelaksanaan program sertifikasi komputer pada Universitas Teknologi Indonesia ditinjau dari komponen program planning sebesar $83,87 \%$, sehingga termasuk kategori baik; Tingkat efektivitas pelaksanaan program sertifikasi komputer pada Universitas Teknologi Indonesia ditinjau dari komponen program implementation sebesar $85,24 \%$, sehingga termasuk kategori baik; Tingkat efektivitas 
pelaksanaan program sertifikasi komputer pada Universitas Teknologi Indonesia ditinjau dari komponen program improvement sebesar $84,17 \%$, sehingga termasuk kategori baik; Tingkat efektivitas pelaksanaan program sertifikasi komputer pada Universitas Teknologi Indonesia ditinjau dari komponen program certification sebesar 84,75\%, sehingga termasuk kategori baik dan Tingkat efektivitas pelaksanaan program sertifikasi komputer pada Universitas Teknologi Indonesia ditinjau dari seluruh komponen model CSEUCLA sebesar $84,55 \%$, sehingga termasuk kategori baik.

\section{DAFTAR PUSTAKA}

Arifin, Z. (2012). Evaluasi pembelajaran. Bandung: Remaja Rosdakarya, 425. Retrieved from http://winarno.staff.iainsalatiga.ac.id/wpcontent/uploads/sites/25/2013/01/34Evaluasi-Pembelajaran.pdf

Bandrujaman, AIP. 2011. Teori dan Aplikasi Evaluasi Program BK, Jakarta: Indeks

Djaali dan P. Mulyono. 2004. Pengukuran Dalam Bidang Pendidikan. Jakarta: Program Pascasarjana Universitas Negeri Jakarta.

Gall, Meredith D., Gall, Joyce dan Borg, Walter R. 2007. Educational Research: An Introduction. New York: Pearson Education.

Mardapi, D. 2012. Pengukuran, Penilaian, dan Evaluasi Pendidikan.Yogyakarta: Nuha Medika.

Munthe, A. P. (2015). Pentingnya Evaluasi Program di Institusi Pendidikan. Scholaria, 5(2), 1-14.

Oriondo, L. Layola, dan E.M.D. Antonio. 1998. Evaluating Educational Outcoms. Manila: Rex Book Store.

Owen, John M. 2006. Program Evaluation: Forms and Appoaches. Crows Nest: Allen \& Unwin.
Petri, H. L., (1986) Motivation : Theory and Research, Belmont, California : Wadsworth Publishing Company.

P4TK. Penjas dan BK. 2010. Modul dan Evaluasi Pelaksanaan BK. Jakarta.

Remmer, H.H., at.al. (1967), A Practical Introduction to Measurement and Evaluation, Apleton-Century Crafts, Inc.

Roswati. (2008). Evaluasi Program/Proyek: Pengertian, Fungsi, Jenis, dan Format Usulan. Jurnal Pendidikan Penabur, 11(11), 64-71.

Rosyanda, D. 2004. Paradigma Pendidikan Demokratis, Sebuah Model Pelibatan Masyarakat Dalam Penyelenggaraan Pendidikan. Jakarta: Kencana Pronada Media.

Stufflebeam, Daniel L. dan Shinkfield, Anthony J. 2007. Evaluation Theory, Models, and Application. San Francisco: Jossey-Bass.

Sukardi, H.M. 2008. Evaluasi Pendidikan Prinsip \& Operasionalnya. Yogyakarta: Bumi Aksara.

Suryanto, Adi, A. Gafur, dan F.X. Sudarsono. 2013. Model Evaluasi Program Tutorial Tatap Muka Universitas Terbuka. Jurnal Penelitian dan Evaluasi Pendidikan, 17(2): 198-214.

Tayibnapis, F.Y. 2000. Evaluasi Program. Jakarta: PT. Rineka Cipta.

Widoyoko Tayibnapis, F. Y. (2000). Evaluasi Program Pembelajaran. Jurnal IImu Pendidikan, 1-16.

Wirawan. 2011. Evaluasi: Teori, Model, Standar, Aplikasi dan Profesi. Jakarta: Rajagrafindo Persada.

YTN, Farinda. 2008. Evaluasi Program dan Intrumen Evaluasi untuk Program Pendidikan dan Penelitian. Jakarta. 